\title{
IAMJ
}

INTERNATIONAL

AYURVEDIC

MEDICAL JOURNAL

ISSN: 23205091

Impact Factor: 5.344

\section{AN OVERVIEW OF RAJASRAVA KALA AND THE ROLE OF RAJASWALA PARICHARYA}

\author{
Harinakshi B ${ }^{1}$, Mamatha $\mathrm{K} \mathrm{V}^{\mathbf{2}}$ \\ ${ }^{1}$ P. G. Scholar, Department of Ayurveda Samhita and Siddhanta, \\ ${ }^{2}$ Professor and Head, Department of Prasooti Tantra and Striroga, \\ Sri Dharmasthala Manjunatheshwara College of Ayurveda and Hospital, Kuthpady, Udupi - 574118, Karnataka, \\ India
}

Corresponding Author: harinis1912@gmail.com

\section{https://doi.org/10.46607/iamj08p4062020}

(Published online: September 2020)

Open Access

(C) International Ayurvedic Medical Journal, India 2020

Article Received:10/09/2020 - Peer Reviewed:20/09/2020 - Accepted for Publication:22/09/2020

Check for updates

\begin{abstract}
Rajasrava Kala is a period where the women undergo tremendous social, physiological and psychological changes in her body. Variations in hormones play an important role in the process of menstruation. Shareera is bound by Doshas and in particular menstruating women have imbalance of various Doshas which manifest in several symptoms of both physiological and psychological conditions like low back pain, abdominal cramps, bloating etc. These symptoms can be mitigated to a large extent by following the ancient tradition of Rajaswala Paricharya as propounded by various Acharyas irrespective of their Prakriti and Vaya. It is of paramount importance that the modern woman undergoes tremendous discomfort in balancing her work and family to meet the demands of present lifestyle.
\end{abstract}

Keywords: Rajasrava Kala; Rajaswala Paricharya; Rutuchakra; Prakriti. 


\section{INTRODUCTION}

Ayurveda is an ancient system of medicine which originated during the Vedic period. Great emphasis is given to prevention of diseases rather than cure by maintaining a balanced life. $A y u$ means life Veda means knowledge/information. Therefore, Ayurveda means 'The Science of Life'. In Ayurveda special importance is given to Stree and as has been said in our Shastras "Yatra Naryaastu Pujyante Ramante Tatra Devataha". Stree is known as an embodiment of the Divine; Hence, Stree Swaasthya is given highest priority by the great Acharyas.

With the onset of menarche, Stree enters the 'reproductive' age of her life. Menstruation or Rajasrava heralds the progression of Kumari to Rajomathi. Rutuchakra means menstrual cycle and the meaning of Chakra means wheel, which revolves continuously. In Stree Shareera it can be seen in form of bleeding through vagina termed as menstruation which occurs every month for the purpose of reproduction. Entire period of 1 month (Chandramaasa - 28 days) is divided in to three phases i.e.

- Rajahsrava (Menstruation) - 3-5 days

- Rutukala (Proliferative phase including ovulation) -12 or 16 days

- RutuVyateetakala (Post-ovulatory phase including Secretory phase) - 9 or 13 days

Rajasrava Kala is a period when there is expulsion of Rajas from the Garbhashaya. The duration of bleeding lasts 3-5 days. During this period the effect of VataDosha is predominant.

Ayurveda describes Rajasrava as a physiological process like many other naturally occurring processes governed by Doshas. Each individual has different Prakriti and each Prakriti is governed by Doshas. Ayurveda describes normal menstruation as one when the Tridoshas are balanced and that which is not associated with any pain and the quantity of blood expelled is not scanty or excessive. The blood should not be unctuous or greasy and the colour should resemble the colour of Rakta Kamala, Lakshya Rasa or Rabbits blood. Different terminology is used to describe the 'menstrual blood' like Artava, Raja, Shonita, Lohita, Pushpa, Rudira and Beeja under different contexts.
The most widely used term for blood is Artava and Rajas.

\section{Rajahsrava kala}

Maasimaasi rajah streenaamrasajamstravatitreham \| (A.H.Sha.1/7)

All Acharyas have described Rajasravakala as bleeding phase. There is however a difference of opinion as to the duration of Rajasrava Kala/Artavasrava Kala.

- Vagbhata - 3 days (A.S. Sha.1/10 and A.H. Sha. $1 / 7)$

- Bhavamishra - 3days (B.P. Pu. Kha.Garbha.2/204)

- Charaka - 5 days (Cha.Chi.30/225)

- Harita - 7 days (Ha.Sam.Sha.1/19)

- Bhela- 5 to 6 days

During this period, the Rajas/Rakta which is formed in the Shareera gets accumulated in the Garbhashaya and if there is no conception then the same is also known as Artava and is discharged as PuranaRajas. This precede the period known as Rutukala. ${ }^{1}$

Maasenopachitam kale dhamaneebyamtadhaartavam | Ishathkrishnamvivarnam cha vaayuryonimukhamnayeth $\| \quad$ (su.sa.soo.3/10) As said by Acharya Sushruta the blood accumulated in the Garbhashayafor the whole month is expelled through the Yoni by Apana Vayu. The blood is carried by both the Dhamanis (uterine vessels and their endometrial capillaries) to the uterus and colour becomes slightly brackish and possesses unique odour/Gandha. Acharya Vishwamitra has observed that hairy thin vessels fill the uterus for the whole month to receive Beeja/Shukra (both Stree and Pumbija). ${ }^{2}$

Above description clearly indicates that menstruation is a result of changes going on in the Stree Shareera and concurrently in the Garbhashaya due to the changes in the internal vasculature. It means the endometrium undergoes physical change eventually resulting in its destruction. Menstruation is the visible manifestation of cyclic physiologic uterine bleeding due to shedding of the endometrium following invisible interplay of hormones mainly through hypothalamus-pituitary-ovarian axis. For the menstruation to occur, the axis must be actively coordinated, endome- 
trium must be responsive to the ovarian hormones (estrogen and progesterone) and the outflow tract must be patent. Once the menstruation starts, it continues cyclically at intervals of 21-35 days with a mean of 28 days. $^{3}$

\section{Sangatana (constitution)}

Artava is made up of Panchamahabhuta in which: Prithvi- Gandhata, Jala maintains Dravata, Teja maintains Ragata., Vayu - Spandana (Which helps in circulation, discharge of regular and proper flow), Akasha Mahabhuta provides necessary passage and flow of Artava due to its inherent LaghutaGuna ${ }^{4}$

\section{Origin and Formation of Artava}

- Rasaathsthanyamaartavamcha

(su.sa.soo.14/10.teeka)

Artava is formed from Rasa Dhatu in the Shareera, Rakta named Rajah is formed in the uterus. The Rajah is thus formed from the Sara or essence part of Rasa Dhatu and same is expelled from the Garbhashaya for 3 days of every month. According to Charaka and Sushruta, Artava is formed from Rasa and the same maintains consistency throughout the formation and up to the eventual expulsion from the uterus. Acharya Vagabhata says Rajas is formed from Rasa and gets accumulated in the uterus and gets expelled as Artava. Acharyas use the word Artava under different contexts. It is also to be noted that the meaning is used inter-changeably.

$>$ Artava as Rajasraval Menstrual blood - It is Shonita, Asrug, Rajah, Rakta, Rudhira, Pushpa, Lohita (Acharya Charaka, Sushruta, Vagbhata and Kashyapa).

> Artava as Streebeeja/ Ovum -It is Shonita, Asrug, Rajah, Rakta (Acharya Charaka, Sushruta, Vagbhata)

\section{Artava Lakshanas}

Artavamshonithamtuaagneyam\| (su.sa.soo.14/7)

The nature of Artava is not Soumya like Rasa (formed from Rasa Dhatu), According to Acharya Sushruta Artava is of Tejo Mahabhuta Pradhana i.e. Agneya Swaroopa. In Sushruta Samhita, Dalhana commented on the Samyoga of Shukra and Artava concept with description about the Swaroopa of Artava as Alpa, Styanibhuta, Sukshma and Asanchari.

\section{Varna [Colour]:}

Colour of Artava is described as Prakruta Varnaas follows:

Gunjaphala - Resembles the juice of lac.

Padma /Rakta Kamal/ Alaktaka - Resembles the juice of red lotus flower.

Indragopa-Resembles crimson red like cochineal insect (cha.sa.chi.30/226)

Sashaasrik - Resembles Rabbit blood (su.sa.sha.2/17, A.san.sha.1/20)

LakshaRasa- Resembles the red fruit of jequirity. (su.sa.soo.3/10)

Ishat Krishna - Resembles brackish colour (A.san.sha.1/22, Ha.sa.sha.1/24)

[Acharyas also says that the colour of Artava depends on the Prakriti of a person by Bhavprakasha.

Yogaratnakara, Bhavamishra have followed Charaka and Sushruta in this regard.]

\section{Gandha [Odour]:}

The odour of Artava is described by Acharyas in the following Shlokas:

\section{Visrataaaamagandhataa \| (su.sa.soo.14/9.dalhana)}

Acharya Sushruta mentions Rakta as of Visra Gandha due to predominant of Prithvi Mahabhuta, Dalhana commented it as Ama Gandha. Artava is of Madhu Gandha which is like the smell of honey (Ma.ni.61/7.madhukosha vyakya)

\section{Artava Pramana}

chathvaarorajasahstreeyaa \| (A.H.sha.3/81)

Acharya Charaka says that the quantity of Rakta/Artava expelled is neither scanty nor excessive and which does not cause any pathological disorder. ${ }^{6}$

Acharya Vagbhata and Sushruta say that the Matra of Artava is of four Anjali.

It is generally observed that one cycle of menstruation expels $80-90 \mathrm{ml}$ of blood and any excess amount is considered as Atipravaha or Menorrhagia.

Maasaannishpicchadaahaa tipancharaatraanubandhi cha | Naivaatibahunaathyalpamaartavamshuddhamaadisheth || (Cha.sa.chi. 30/225)

Rajasrava kala is enunciated in the Shastras as a bleeding phase. Artava/Rajas flow lasting 5 days and not associated with any burning sensation or associated pain in the Shareera is defined as normal $R a$ - 
jasrava. Further, it has also been said that the Artava/Rajas should not be too scanty or excessive, is not unctuous in nature, foul smelling and is not discolored and then Rajasrava is considered to be normal.

Artava/Rajas is said to be Shuddha when it has Prakruta Varna, Gandha, Matra/Pramana and Swaroopa as defined in the Shastras. Apart from this the Artava should not stain clothes when washed and is discharged at proper Masaanumasika Kala then also the Artava is said to be Shuddha. If Artava does not exhibit these Lakshana's, it is indicative of Vikruta Avastha as it can manifest in many problems related to Stree Swaasthya like common gynecological disorders.

\section{Rajaswala Charya}

Acharyas explain how a Stree should live during $R a$ jasrava kala as under,

- From the first day on the onset of Rajasrava it is advised that the Stree should follow celibacy.

- She should abstain from all sorts of physical activities including household activities other than those that are absolutely necessary for her day to day life.

- $\quad$ Stree should not sleep during daytime, not apply Kajal, and avoid combing her hair. Not shed tears, not bathe nor anoint self with decorative ornaments and also desist from paring of nails.

- She should avoid talking and laughing loudly.

- She should not fast during these days and should consume foods like Havishya i.e., meal made of ghee, Shali rice and milk, Yavaka i.e., meal made of barley \& milk and the same should be cooked in a clean unbroken vessel made of clay.

- She should sleep on a mattress made of Darbha (holy grass used in sacred ritualistic practices in Hinduism) and the mattress should be laid on the floor.

- She should avoid Panchakarma therapies like Nasya, Swedana and Vamana ${ }^{8}$.

\section{DISCUSSION}

\section{Role of Dosha in Rajahsrava}

Ayurveda describes that each individual has different Prakriti as defined by Doshas.
- Pittaja Prakriti individuals display more Pittaja quality Lakshanas.

- Vataja Prakriti individuals display more Vataja quality Lakshanas.

- KapahjaPrakriti individuals have more Kaphaja quality Lakshanas.

It is very important to note that the 'Vata Dosha' is predominant during Rajasrava Kala irrespective of the Prakriti of the individual. Due to the heightened presence of Chala Guna of Vata there is corresponding increase in the movement of Vayu which further enhances the movement of Dravyas in the Garbhashaya. One of the types of Vata i.e., Apana Vayu is responsible for the elimination of Mala, Mutra and Rajas. During menstruation each individual of different Prakriti is governed by different Doshas. In general, it is observed that during Rajasrava there is Kapha Dosha Sanchaya and corresponding Vata Prakopa and Pitta Prashamana Avastha.

Menstrual flow can be classified according to their Prakriti as

\section{- Vataja Menstrual Flow:}

When there is Prakopa of Vata in Garbhashaya the Srotas or Dhamani gets constricted thereby reducing the flow of blood and nutrients to the endometrium. This is also due to the inherent characteristics of Vata as defined by its Sheeta and KharaGuna that disrupts the normal flow of blood through the arteries in the Garbhashaya. When this depletion of blood occurs, there is tremendous pain like low back ache, muscle cramps and body ache. This condition which afflicts people of Vataja Prakriti the intensity of pain is severe resulting in more discomfort. Also, if during this period if they consume Vatakara Ahara like Lavana Katurasa Yukta Aharas and indulge in Viharas like strenuous physical work then the intensity of pain increases substantially.

\section{- Pittaja Menstrual Flow:}

When there is Pitta Prakopa in the Garbhashaya there is smooth flow of menstrual blood due to its inherent Ushna and Teekshna Guna of Pitta. They generally have 'less' severity of low back pain, abdominal cramps etc., instead they have skin eruptions like acne/pimples and burning sensation. Slight increase in 
body temperature is also seen. These characteristics can be seen in Pittaja Prakriti individuals and if they consume less Pittakara Aharas like Katu, Kshara, Teekhna, Lavana Yukta Aharas then they can reduce the aforesaid symptoms.

\section{- Kaphaja Menstrual Flow:}

When there is Kapha Prakopa in the Garbhashaya there is heavy expulsion of blood and its constituents. The exudates are unguent, unctuous, thick and mucous in nature because of Guru, Manda, Sheeta, Slakshana and Mritsna Guna of the Kapha. Individuals suffering from this condition become lethargic and lazy. The flow of blood too is inconsistent and of longer duration. These characteristics increase in individuals of Kaphaja Prakriti and if they avoid Madhura, Snigdha, Guru Aharas they can overcome the aforesaid symptoms to a large extent. First and foremost, it is said that during menstruation there is a process of Shodhana in the Stree. It means the Stree is undergoing a natural process of purification and thereby removing impurities from the Shareera. The Rajaswala Paricharya is as Shodhana procedure which is similar to the Ashta Mahadoshakara Bhavas as described in Ayurveda. Since there is heightened dominance of Vata during this period there is less dominance of Pitta and Kapha i.e., Pitta in Prashamana Avastha and Kapha in Sanchaya Avastha. As said above in Rajaswala Paricharya that a menstruating woman should practice 'Celibacy' or 'Brahmacharya' because when she is undergoing austerity and purification process any sexual intercourse may lead to impairment of the future child thus born, It is mentioned in Sushruta Samhita that the conception, if it occurs, the ensuing offspring will either have congenital deformity or short life span. Also, it is to be noted that if the menstruating women engages in coitus then this causes imbalance in energy levels which is detrimental to her health. Further it is also mentioned that if there is copulation the lifespan of husband shortens, and he tends to lose virtuousness and glory.

As mentioned in the Sushruta Samhita and Angirasa Smriti any physical exertion is to be avoided due to the heightened presence of Rajas in her body. If there is any physical exertion (including talking and laugh- ing loudly) over a long period of time then she will not be able to be in a healthy condition due to imbalance of Doshas, and any future child may face severe health problems. It is also said that she should avoid cooking because when she is in a state of Rajasika there will be a conflict of energy since it is believed that food are the carriers of positive energy.

As mentioned by Acharya Sushruta, the women during Rajasrava kala must not bathe nor sleep during the daytime, apply Kajal and adorn ornaments etc. due to the imbalance of Doshas. For e.g. there is already Agnimandhya in Rajasrava Kala, sleeping during the daytime increases the Kapha thereby increasing the intensity of Agnimandhyathva. Segregation is also advised as part of austerity and purification process or Shodhana. This is for obvious reasons that segregation is necessary for the management of blood loss hygienically. In modern times the use of sanitary pads has reduced this segregation but it is advisable that she being in the heightened state of Rajasika does not transfer negative energy to others through touch and the same principle holds true if she is also allowed to cook. As per Sushruta Samhita consumption of food should be moderate because during this period there is Jataragni Mandyatva and therefore should abstain from consuming Katu, Teekshna, Amla, Lavana Yukta Ahara for better digestion. It is better that Rajasika food made of meat or meat products is avoided for inhibiting the Prakopa of Doshas. In summation it is advised that the menstruating woman eats only Satwika foods for maintenance of her physiological health.

As per tradition, it is also advised that the woman should not perform any religious rituals or enter a temple because a consecrated temple is a place of spiritual enlightenment of the conscience. High positive energy emanates from a consecrated temple and when a menstruating woman who has heightened Rajasika enters then there is obvious imbalance of energy which leads to great physiological damage to her health. Therefore, Dharma Shastras say that a menstruating woman should abstain from entering a temple for her own spiritual and physiological well-being. 
Finally, in summation, the Stree who is on menstruation should follow certain rituals on the fourth day of her menstrual cycle. Acharyas say that on the $4^{\text {th }}$ day she should take a sacred ritualistic bath, use unguents and wear white garments. She should also adorn herself with ornaments, carry garlands made of flowers chanting with piousness sacred hymns and look at her husband. Further, it is also mentioned that she should with purity of thought and mind offer oblations and pay obeisance to Agni Deva, Lord Vishnu, Skandas, Brahmanas, Gou Mata etc., this helps her in increasing Satvika Guna which will eventually help her in producing a healthy offspring. Rajahswala Paricharya if is not followed properly may lead to Ashta Artava Dushti or Yoni Vyapath which is associated with present era menstrual problems like dysmenorrhea, menorrhagia etc., Hence it is necessary to follow $R a$ jaswala Paricharya during Rajahsrava kala. In a Study conducted by researchers it was found that candidates who were chosen to follow the traditional $R a$ jaswala Paricharya had exhibited great improvement in their physiological and psychological conditions. They reported less symptoms of pain associated with menstruation especially low back pain and abdominal cramps. Therefore, it can be said that following $R a$ jaswala Paricharya is helpful in relieving many discomforts in menstruating women even during the modern times. (Ref: Rajaswala Paricharya - Effect on Menstrual Cycle and Its Associated Symptoms by Dr Pallavi Pai et al)

\section{CONCLUSION}

Women play an important role in the socio-political structure of the society. Their role is more assertive than ever before in the present times. Therefore, their health and well-being is of prime importance for the progress of humankind. Ayurveda accords special importance to Stree and Stree Swaasthya and in particular utmost care is of prime importance during her reproductive years. Rajasrava Kala/Menstruation period is a period when the Stree undergoes social, physiological and psychological changes. Modern women have an added responsibility of family and work. Therefore, menstruating women undergo tremendous difficulty in fulfilling their day to day chores along with additional health concern, Modern lifestyle has more or less reduced women to bundle of agonies and it is also difficult for her to withstand the pressure resorting her to find solace in modern medicine. During ancient times the concept of PMS i.e., pre-menstrual syndrome was totally absent. But, as has been observed and experienced by a whole lot of women PMS afflicts majority of the population cutting across all age groups. It is to be noted that physiological symptoms persist more during Rajasrava Kala than the Rutukala or Ruruvyateeta Kala. She will be at the lowest ebb of her physical fitness. Physically active woman suffers a lot during this phase. Additional symptoms may persist along with symptoms like shoulder pain, joint pain, hyper-acidity etc., Also, psychologically she may be prone to short temper and anger.

Most of the modern ailments afflicting women are a direct result of the modern lifestyle. For e.g. Obesity, Infertility, Menhorragia, Dysmenorrhea etc., afflict more people than ever before. Rajaswala Paricharya as practiced during the ancient times may be the solution for treating these symptoms. Some of the 'rituals' practiced by ancient women may not too practical in the present day and age however, there is tremendous scope for mitigating the discomfort by practicing these regimens. Paricharyas as prescribed by the Acharyas can be followed by modern women to a large extent for minimizing the pain and associated symptoms adhering to Ahara-Vihara Paricharyas. Consuming of Aharas which are Satmya to individuals like Snigdha, Laghu, Madhura Yukta Ahara etc., and Viharas like Yoga and Meditation help the women in overcoming most of symptoms. This may also help her to mitigate any underlying gynecological disorders.

\section{REFERENCES}

1. Agnivesha, Charaka, Charaka Samhita, Mahatigarbhavakranti Shareeram, Commentary, Chakrapanidatta, Acharya Y.T(ed), Chaukambasurabharatiprakashan, Varanasi; 2017, p: 317, Pp: 738.

2. Sushrutha, SushruthaSamhita, Shonitavarnaneeya, Nibandasangraha Commentry, Dalhana and Gayadasacharya, Acharya Y.T(ed), Chaukambasurabharatiprakashan, Varanasi; 2017, p: 62, Pp: 824. 
3. D.C. Dutta, D.C. Dutta's Textbook of Gynecology, Menstruation, Edited by HiralalKonar, New Central Book Agency Ltd Publishers, Kolkata; 2013, p:85, Pp:686.

4. Sushruta, Sushruta Samhitha, Shonitavarnaneeya, Nibandasangraha Commentry, Dalhana and $\mathrm{Ga}-$ yadasacharya, Acharya Y.T(ed), Chaukambasurabharatiprakashan, Varanasi; 2017, p: 60, Pp: 824.

5. Sushruta, Sushruta Samhita, Shukrashonitashuddhishareera, Nibandasangraha Commentry, Dalhana and Gayadasacharya, Acharya Y.T(ed), Chaukamba surabharati prakashan, Varanasi; 2017, p: 348, Pp: 824.

6. Agnivesha, Charaka, Charaka Samhita, Yonivyapathchikistaadhyaya, Commentary, Chakrapanidatta, Acharya Y.T(ed), Chaukamba surabharati prakashan, Varanasi; 2017, p: 643, Pp: 738.

7. Madhavakara, Madhava nidana, K R Srikantamurthy, english translation book, Choukamba orientalia, Varanasi; 2004, p: 221, Pp: 310

8. Agnivesha, Charaka, Charaka Samhita, Jaatisootreeyashaareera, Commentary, Chakrapanidatta, Acharya Y.T(ed), Chaukamba surabharatiprakashan, Varanasi; 2017, p: 340, Pp:738.

\section{Source of Support: Nil}

\section{Conflict of Interest: None Declared}

How to cite this URL: Harinakshi B \& Mamatha K V: An Overview of Rajasrava Kala and the Role of Rajaswala Paricharya. International Ayurvedic Medical Journal \{online\} 2020 \{cited September, 2020\} Available from: http://www.iamj.in/posts/images/upload/2498_2504.pdf 